\title{
THE EFFECT OF A PROTEIN-XANTHOPHYLL CONCENTRATE FROM ALFALFA (PHYTOBIOTIC) ON ANIMAL PRODUCTION - A CURRENT REVIEW
}

\author{
Eliza Gaweł ${ }^{1}$, Mieczysław Grzelak ${ }^{2}$ \\ ${ }^{1}$ Department of Forage Crop Production, Institute of Soil Science and Plant Cultivation - \\ State Research Institute in Puławy, Czartoryskich 8, 24-100 Puławy, Poland \\ ${ }^{2}$ Department of Grassland Sciences and Natural Landscape, University of Life Sciences in Poznań, \\ Wojska Polskiego 38/42, 60-637 Poznań, Poland
}

\begin{abstract}
One of the supplements that can replace antibiotic growth promoters is a protein xanthophyll extract from the leaves of alfalfa. Green matter of alfalfa contains 17-22\% of total protein, rich in non-essential (exogenous) amino acids, saturated, monounsaturated and polyunsaturated fatty acids, vitamins, minerals, and organic acids. The crude fibre content in green matter of alfalfa is relatively high (about $\mathbf{2 3 . 0}-\mathbf{3 0 . 0} \%$ dry weight). However, protein-xanthophyll extract (EFL) contains about 1-2\% of crude fibre. Like the whole plants of alfalfa, the protein-xanthophyll extract contains secondary metabolites such as plant phytoestrogens (isoflavones and coumestrol) and antinutritional components (phytates, L-canavanine and saponins). Protein-xanthophyll concentrate (PX) as a natural feed supplement has a positive effect on animal organisms. When supplemented to animals, this extract enhanced production results, increased feed efficiency, and improved the quality of meat, milk and eggs. Also, PX reduced methane emissions and soil pollution with nitrogen compounds when used in animal nutrition. The aim of this review was to gather the current literature describing the effects of using protein-xanthophyll extract in animal nutrition.
\end{abstract}

Key words: alfalfa, protein xanthophyll concentrate (PX), chemical composition, phytobiotic in animal production

In 2006, EU countries imposed a ban on using antibiotic growth promoters in livestock nutrition. The ban resulted from the emergence of antibiotic resistance in pathogenic bacteria which increases the hazard to human life and health. Therefore, the purpose of feeding animals is to enhance their natural resistance and maintain optimal gastrointestinal microflora by introducing safe, natural feed supplements and other nutrients to their diet (macro- and micro elements, vitamins, amino acids, and secondary metabolites: saponins, isoflavones, phytoestrogens). The most common feed supplements are prebiotics, probiotics, synbiotics, preservatives, herbs, feed enzymes, antioxidants, flavouring and aromatic substances, deodorizing preparations 
and others, whose task is to meet the nutritional needs of animals, improve functional characteristics, and increase feed efficiency.

One of the supplements that can replace antibiotic growth promoters is a protein-xanthophyll concentrate (PX) from the leaves of alfalfa. In ancient times, its nutritional value was highly appreciated and it was called Herba Medica and alfalfa (best feed). The aim of this review was to gather the literature describing the effects of using protein xanthophyll concentrate in animal nutrition. This review discusses recent developments in the use of PX to benefit animal production.

\section{Production and chemical composition of PX}

Protein xanthophyll concentrate is obtained from the juice of alfalfa leaves devoid of indigestible fibre by extracting protein, macronutrients and vitamins and by adding vitamin $\mathrm{C}$. This product is highly valuable as it has a favourable chemical composition with a high content of protein, vitamins and minerals. It also contains many amino acids, about $50 \%$ of which are essential amino acids and conditionally essential (semi-essential) amino acids such as cystine, cysteine and tyrosine, synthesized in the animal or human body from other essential amino acids.

In the process of production of a protein-xanthophyll concentrate, drying of juice from alfalfa takes place at a protein coagulation temperature of $85-90^{\circ} \mathrm{C}$ so that the proteins associated with carotenoids and chlorophyll pigments retain their properties (pigments). After its enrichment with large amounts of vitamin C $(600 \mathrm{mg} / \mathrm{kg})$, the product is stored in the refrigerator or in an inert gas without light exposure for use in human nutrition as alfalfa leaf extract (known in French as EFL, "l'Extrait Foliaire de Luzerne").

Green matter of alfalfa contains $17-22 \%$ of total protein, rich in non-essential (exogenous) amino acids, saturated (palmitic, stearic), monounsaturated (oleic acid) and polyunsaturated (linoleic, linolenic) fatty acids, crude fat (9-10\%), vitamins $(0.09 \%$ in total) A ( $\beta$-carotene), B1, B2, B3 (PP), B5, B6, B8, B9, B12, C, D, E, K and $\mathrm{U}$, and minerals (13-14\%): $\mathrm{Ca}, \mathrm{Cu}, \mathrm{Fe}, \mathrm{Mg}, \mathrm{Mn}, \mathrm{P}, \mathrm{K}, \mathrm{Zn}$ and $\mathrm{Si}$, organic acids: malic and fumaric (Bertin, 2008; Grela, 2008; Grela and Kowalczuk-Vasilev, 2010; Zanin, 2009). The crude fibre content in green matter of alfalfa is relatively high (about 23.0-30.0\% dry weight), and varies from variety to variety. The dry weight of alfalfa includes not only the nutrients, minerals and vitamins, but also phytochemical substances: carotene, chlorophyll, coumarin, beta-sitosterol, fumaric acid, isoflavones, alkaloids, saponins, cryptoxanthin, daidzein, genistein, limonene, lutein, and zeaxanthin (Grela and Kowalczuk-Vasilev; 2010; Zagórka and Głowniak, 2008). Protein-xanthophyll concentrate (EFL), like the whole plants of alfalfa, contains secondary metabolites such as plant phytoestrogens: isoflavones and coumestrol and antinutritional components: phytates, L-canavanine and saponins. The rich chemical composition of the alfalfa leaf concentrate makes it useful in human nutrition as a dietary supplement in the prevention and treatment of various diseases. In animal nutrition, it is a phytobiotic which can replace antibiotic-based growth promoters (Grela, 2008). 


\section{Effect of PX on animal growth and feed utilization}

National research has shown that the addition of $1.5 \%$ and $3 \%$ of PX to the feed for turkeys increased their body weight gains and reduced feed consumption (Czech et al., 2010 a; Grela, 2008). However, Tartari et al. (1992) obtained an increase in performance of pigs after the application of only $2 \%$ concentrate. Increasing its quantity to 4 and $6 \%$ did not produce a similar effect. PX used in the feeding of pigs had a positive effect on muscle deposition in porkers and reduced the amount of saturated fatty acids in favour of mono- and polyunsaturated acids (Grela, 2008). The high digestibility of crude protein mixtures with 10-20\% PX, comparable and similar to the mixture of soy pellets was obtained by Bourdon et al. (1980). In the feeding of carp, alfalfa PX concentrate added in the amount of $2-3 \%$ to the traditional feeds (triticale, barley, wheat) had a positive impact on growth, length, and weight of the fish (Rechulicz and Stec, 2008). Furthermore, it increased the utilization of feed nutrients in beef cattle (Klebaniuk and Kowalczuk-Vasilev, 2010).

The feed supplement HUMES, consisting of alfalfa and humic materials (powdered lignite) improved resistance of laying hens, broilers and quails, increased health of the flock and egg production, and enhanced the colour of eggs and carcasses, as well as physical and chemical properties of eggs (Bubel et al., 2010).

Literature mostly describes the positive effects of PX use in animal nutrition, but some authors found no such effects of this dietary supplement for animals. For example, Dong et al. (2007) obtained the same performance in broilers from control and experimental groups with the addition of supplements, and the positive effect of Polysavone extract in this study concerned only the increased resistance and lower abdominal fat content in birds. Güçlu et al. (2004) also found no increase in live weight gains, egg production and feed efficiency in quail following the introduction of dried alfalfa to the diet of birds. In a study by Japanese researchers, productivity growth among chickens and pigs after the application of alfalfa concentrate was not proven (Ueda and Ohshima, 1989). Wang et al. (2008) observed only an increase in total protein content of meat sheep.

\section{PX source of vitamins for animals}

Protein-xanthophyll concentrate from alfalfa is a source of various vitamins and minerals for animals (Bertin, 2008). In feeding of broilers and laying hens, a high content of carotenoids is particularly important as they increase vitamin A level in egg yolks and give them an intense yellow colour. Good egg production and enrichment of eggs in this vitamin are obtained by replacing $25 \%$ of soy pellets with an alfalfa concentrate in standard rations based on soy pellets and corn (Hanczakowski and Szymczyk, 2010). In other studies, grazing and feeding livestock with dried alfalfa supplement enriched milk of cows (Calderon et al., 2007) and blood plasma and fat of lambs with vitamin E (Dian et al., 2007).

\section{Impact of PX on the immune and hematopoietic system of animals}

The extract of alfalfa consists of biological compounds which actively stimulate immune and hematopoietic systems of young turkeys (Zagórka and Głowniak, 2008; Dong et al., 2007). After administration of $1.5 \%$ and $3 \%$ of PX concentrate to 
6-week-old turkeys, leukocyte count and iron content increased, and the amount of blood neutrophils decreased (Czech et al., 2010 b). Also, utilization of feed nutrients was improved (Klebaniuk and Kowalczuk-Vasilev, 2010). In the studies on pigs addition of $2 \%$ PX pellets instead of ground wheat to complete feedingstuffs increased their resistance and lowered blood cholesterol levels, especially at the beginning of fattening, but did not change the indices of $\mathrm{Ht}, \mathrm{Hb}$ and $\mathrm{RBC}$ (Czech and Semeniuk, 2008; Khaleel et al., 2005). Saponins in alfalfa enhance the secretion of bile acids and increase the secretion of steroids (cholesterol excretion from the body) and also reduce the total cholesterol to HDL cholesterol ratio in the blood of animals. Stimulation of lipid changes in the body of animals and reduction of intestinal cholesterol absorption due to large amounts of saponin in alfalfa was also reported by other authors (Czech et al., 2010 c; Reshef et al., 2006).

The use of iron-rich alfalfa concentrate in feeding lambs significantly improved hematological blood indices: hematocrit $(\mathrm{Ht})$, hemoglobin $(\mathrm{Hb})$ and erythrocytes (RBC) (Kowalczuk-Vasilev et al., 2010). According to Seguin et al. (2004), an increase in the value of red blood cell indices is associated with better absorption of elements involved in the erythropoietic processes. In the blood picture of turkeys there was no such response after the application of PX supplement (Krauze and Grela, 2008).

\section{PX and the quality of animal products and antioxidant processes}

Oxidative processes, which occur in meat and meat products degrade their flavour, nutritional value and colour, and lead to the degradation of fats and proteins, the consequence of which is their limited storage life. As the nutrition of animals was previously proven to affect the quality of animal products, it should be sought to use natural antioxidants found in plants to delay oxidative processes in meat and its products. Green matter from alfalfa and dried alfalfa, as well as PX concentrate, possess antioxidant properties, so they can improve the quality of the meat. Grazing on alfalfa was found to result in good quality meat, free of off-flavour (Hopkins and Nicholson, 1999). According to Young et al. (2003), flavour of the meat of pasturefed lambs was affected by the high content of $\beta$-carotene in alfalfa. Lamb flavour depends on the content of the mixture of fatty acids and skatole (3-methyloindole). The odour of bovine meat is mainly formed by linolenic acid oxidation products derived from pasture sward (Priolo et al., 2001). Ferulic acid and vitamin C contained in alfalfa have an antioxidant effect on pig meat (Ben Aziz et al., 2006). Karwowska et al. (2007) initially did not confirm this finding in a study on the oxidative stability of ham, but their further research on the introduction of PX to the diet of pigs showed an increase in the share of red meat $\left(\mathrm{a}^{*}\right)$ and a decrease in the value of the total change in meat colour $\left(\Delta \mathrm{E}^{*}\right)$ (Karwowska, 2008). Similarly, Dolatowski (2008) obtained good quality meat and products from turkeys and pigs after applying $1.5 \%$ protein xanthophyll concentrate from alfalfa. An increase in low-molecular blood antioxidants, i.e. total antioxidative potential (FRAP), uric acid, vitamin $\mathrm{C}$ and glutathione was also reported by other authors (Ognik and Czech, 2010; Ognik and Patkowski, 2010). Supplementation of the lamb diet with $3 \%$ PX concentrate also increased the amount of entrecôte in the carcass while lowering fat deposits and the amount of 
bone in the thigh (Patkowski et al., 2010). It also improved the deposition of muscles and reduced deposition of fat in lamb carcasses by $90 \%$ above the sirloin eye and by 100\% above the ribs (Szymanowska et al., 2010).

The advantages of protein-xanthophyll supplement in animal nutrition include a decrease in the amount of triacylglycerol in the egg yolk of quail (Güçlu et al., 2004) and an increase in reproduction of sows and survival of piglets in a litter, as well as obtaining a higher weaning weight of piglets (Grela and Pietrzak, 2010).

\section{PX and the environment protection}

Fermentation in the digestive tract of animals causes the production of gases such as methane, hydrogen and carbon dioxide, which are excreted into the atmosphere. Methane is particularly important because of its powerful "greenhouse effect". Farmed animals are considered to be the main source of methane of natural origin. Secondary metabolites found in plants such as saponins, flavonoids and tannins reduce the formation of this gas, which is why they are used to manipulate the metabolism of animals and to reduce the development of methanogenic bacteria. One method of such interference may be to reduce the population of protozoa which decrease the efficiency of cellulose digestion in the rumen of cattle by administering saponin concentrate from alfalfa constituting 1\% of dry matter intake (SzumacherStrabel et al., 2010; Szumacher-Strabel and Cieślak, 2010). Introduction of 1.5\% PX concentrate of alfalfa to the mixtures for pigs reduced organic and inorganic pollutants in the air inside the piggery and significantly decreased methane concentration from 18.8 to $7.7 \mathrm{mg} / \mathrm{m}^{3}$ (Grela et al., 2010). Tannin-containing sainfoin fed to ruminants inhibits the production of gas and prevents the formation of foam in the rumen, which protects animals from bloat (McMahon et al., 1999).

Another threat to the environment is a low level of assimilation of protein foods, whose excess, excreted in the urine and feces of animals, can contaminate the soil environment with nitrogen compounds not used by plants. One method of increasing the absorption of nitrogen from the feed and reducing emissions of ammonia and other odours in the piggery is to use a PX alfalfa supplement in feeding pigs (Grela et al., 2008; Grela et al., 2010). It should be noted that the addition of dried alfalfa to the rations did not increase the total mass of manure produced by chickens and pigs, which also has a positive impact on the environment (Yen, 2004).

\section{Conclusion}

After the ban on antibiotic feed supplements, alfalfa concentrate may be important as a dietary supplement for animals. It has been shown to have positive effects on the body of animals. Introduction of PX to animal diets increases weight gain, muscle development, content of mono- and polyunsaturated fatty acids and animal resistance to disease, stimulates their immune and hematopoietic systems, as well as reducing feed consumption. Also, it lowers the level of cholesterol, improves hematological indices of blood, increases nutrient utilization, and protects the natural environment by reducing nitrogen losses and methane emissions. Furthermore, it improves the quality of animal products. 


\section{References}

Ben Aziz A., Grossman S., Budowski P., Ascarelli I., B ondi A. (2006). Antioxidant properties of lucerne extracts. J. Sci. Food Agric., 19 (10): 605-608.

B ertin E. (2008). Alfalfa leaf extract (EFL). In: Alfalfa in human and animal nutrition, Grela E.R. (ed.). Stow. Rozwoju Regionalnego i Lokalnego "Progress” Dzierdziówka-Lublin, 3: 29-37.

B ourdon D., Perez J.M., Henry Y., Calmes R. (1980). Valeur energetique et azotée d'un concentré de protéines de luzerne le PX1 utilisation par porc en croissence-finition. Journées Rec., Porcine en France, pp. 227-244.

Bubel F., Grzelak A., Opaliński S., Tronina P. (2010). Dietary feed additive based on alfalfa (Medicago sativa L.) and humic materials - production technology and chemical composition. In: Alfalfa in human and animal nutrition, Grela E.R. (ed.). Stow. Rozwoju Regionalnego i Lokalnego "Progress" Lublin-Sandomierz, 6: 68-76.

Calderon F., Chauveau-Duriot B., Pradel P., Martin B., Graulet B., Doreau M, Nozi ere P. (2007). Variations in carotenoids, vitamins A and E, and color in cow's plasma and milk following a shift from hay diet to diets containing increasing levels of carotenoids and vitamin E. J. Dairy Sci., 90: 5651-5664.

C z e c h A., S e m e n i u k W. (2008). Blood metabolic profile of pigs fed the diets with protein-xanthophyll (PX) concentrate of alfalfa. In: Alfalfa in human and animal nutrition, Grela E.R. (ed.). Stow. Rozwoju Regionalnego i Lokalnego "Progress” Dzierdziówka-Lublin, pp. 107-119.

C z e ch A., O g n i k K., Gre la E.R. (2010 a). Efficiency of alfalfa concentrate (PX) in turkey hens' feeding. In: Alfalfa in human and animal nutrition, Grela E.R. (ed.). Stow. Rozwoju regionalnego i Lokalnego "Progress" Dzierdziówka-Lublin, 6: 164-165.

Czech A., Ognik K., Kowalczuk-Vasilev E. (2010 b). Influence of PX concentrate of alfalfa (Medica sativa L.) additive in turkey hens' feeding on hematological indices of blood. In: Alfalfa in human and animal nutrition, Grela E.R. (ed.). Stow. Rozwoju Regionalnego i Lokalnego "Progress" Dzierdziówka-Lublin, 6: 166-167.

Czech A., Ognik K., S e meniuk W. (2010 c). Effect of PX concentrate of alfalfa in turkey hens' feeding on blood biochemical parameters. In: Alfalfa in human and animal nutrition, Grela E.R. (ed.). Stow. Rozwoju Regionalnego i Lokalnego "Progress" Dzierdziówka-Lublin, 6: $168-169$.

D i a n P.H.M., Chauve a u - D u ri ot B., Prado I.N., P r a che S. (2007). A dose-response study relating the concentration of carotenoid pigments in blood and reflectance spectrum characteristics of fat to carotenoid intake level in sheep. J. Anim. Sci., 85: 3054-3061.

D o l a t o w s k i Z.J. (2008). Meat quality and their products from pigs and turkey fed diet supplementation with protein-xanthophylls (PX) concentrate of alfalfa. In: Alfalfa in human and animal nutrition, Grela E.R. (ed.). Stow. Rozwoju Regionalnego i Lokalnego "Progress" Dzierdziówka-Lublin, 3: $93-105$.

D ong X.F., G a o W.W., T ong J.M., J i a H.Q., S a R.N., Z h ang Q. (2007). Effect of Polysavone (alfalfa extract) on abdominal fat deposition and immunity in broiler chickens. Poultry Sci., 86: 1955-1959.

Gre la E.R. (2008). Nutritive value of alfalfa and its utilization as protein-xanthophylls concentrate in animal feeding. In: Alfalfa in human and animal nutrition, Grela E.R. (ed.). Stow. Rozwoju Regionalnego i Lokalnego "Progress" Dzierdziówka-Lublin, 3: 77-91.

Grela E.R., S e men i u k W. Fl or e k M. (2008). Effects of protein-xanthophylls (PX) concentrate of alfalfa additive to crude protein-reduced diets on nitrogen excretion, growth performance and meat quality of pigs. J. Central Eur. Agric., 9, 4: 669-676.

Gre la E.R., K ow a l c z u k - V a s i l e v E. (2010). Chemical composition, nutritive value and usefulness of alfalfa products in human and animal nutrition. In: Alfalfa in human and animal nutrition, Grela E.R. (ed.). Stow. Rozwoju Regionalnego i Lokalnego "Progress" Dzierdziówka-Lublin, 6: $13-25$.

Gre la E.R., P i e tr z a k K. (2010). Efficiency of alfalfa concentrate (PX) after flushing mixtures supply in sow feeding. In: Alfalfa in human and animal nutrition, Grela E.R. (ed.). Wyd. Stow. Rozwoju Regionalnego i Lokalnego "Progress" Dzierdziówka-Lublin, 6: 174-175.

Gre la E.R., K u s i or G., D r a b i k A. (2010). Influence of alfalfa concentrate (PX) in fattening diets 
on emission of gaseous air pollutants. In: Alfalfa in human and animal nutrition, Grela E.R. (ed.). Stow. Rozwoju Regionalnego i Lokalnego "Progress” Dzierdziówka-Lublin, 6: 178-179.

G ü çlu B.K., Iş c an K.M., Uy a nik F., R ren M., A ğ c a A.C. (2004). Effect of alfalfa meal in diets of laying quails on performance, egg quality and some serum parameters. Arch. Anim. Nutr., 58 (3): 255-263.

Hanczakowski P., S zy m c zyk B. (2010). Leaf protein concentrate from alfalfa as a source of vitamin A for broiler chickens and laying hens. In: Alfalfa in human and animal nutrition, Grela E.R. (ed.). Stow. Rozwoju Regionalnego i Lokalnego "Progress" Dzierdziówka-Lublin, 6: 172-173.

Hopkins D.L., Nichols on A. (1999). Meat quality of wether lambs grazed on either saltbush (Atriplex nummularia) plus supplements or lucerne (Medicago sativa). Meat Science, 51, 1: 91-95.

Karw ow s k a M., D o lat ow s k i Z.J., Gre la E.R. (2007). Effect of dietary supplementation with extracted alfalfa meal on oxidation stability of cooked ham. Pol. J. Food Nutr. Sci., 57, 4 (B): $271-274$.

K a rw o w s k a M. (2008). Effect of applying alfalfa extract to the diet of pigs on meat colour. Żywność. Nauka. Technologia. Jakość, 5 (60): 282-288.

Khal e el A.E., Gad M.Z., El-M r a ghy S.A., Hi fnaw y M.S., A b d el-S a t t a r E. (2005). Study of hypocholesterolemic and antiatherosclerotic properties of Medicago sativa L. cultivated in Egypt. J. Food Drug. Anal.., 13: 212-218.

K lebaniuk R., Kowa lczuk-Vasilev E. (2010). Effect of protein-xanthophyll concentrate of alfalfa (Medicago sativa) in feeding of fattening cattle on enzymes activity in blood plasma. In: Alfalfa in human and animal nutrition, Grela E.R. (ed.). Stow. Rozwoju Regionalnego i Lokalnego "Progress" Dzierdziówka-Lublin, 6: 188-189.

Kowalczuk-Vasilev E., Klebaniuk R., Patkowski K. (2010). Effect of PX concentrate of alfalfa (Medicago sativa) on haematological indices of lambs' blood. In: Alfalfa in human and animal nutrition, Grela E.R. (ed.). Stow. Rozwoju Regionalnego i Lokalnego "Progress" Dzierdziówka-Lublin, 6: 186-187.

Kra u ze M., Gre la E.R. (2008). The influence of addition protein-xanthophyll extract (PX) from alfalfa on hematological and biochemical turkeys' blood parameters. In: Alfalfa in human and animal nutrition, Grela E.R. (ed.). Stow. Rozwoju Regionalnego i Lokalnego "Progress" DzierdziówkaLublin, pp. 121-127.

McMahon L.R., Majak W., McAllister T.A., Hall J.W., Jones G.A., Popp J.D., C h e n K-J. (1999). Effect of sainfoin on in vitro digestion of fresh alfalfa and bloat in steers. Can. J. Anim. Sci., 79: 203-212.

O g n i k K., C z e c h A. (2010). Effect of dietary supplemental protein-xanthophyll PX concentrate of alfalfa on blood antioxidative potential of turkey hen. In: Alfalfa in human and animal nutrition, Grela E.R. (ed.). Stow. Rozwoju Regionalnego i Lokalnego "Progress" Dzierdziówka-Lublin, 6: $170-171$.

Ognik K., Patkows ki K. (2010). Effect of PX concentrate of alfalfa (Medicago sativa) on antioxidative potential of lamb blood. In: Alfalfa in human and animal nutrition, Grela E.R. (ed.) Stow. Rozwoju Regionalnego i Lokalnego "Progress” Dzierdziówka-Lublin, 6: 180-181.

Pat kowski K., Szy man ow ska A., Grela E.R., Gruszecki T.M., Szy manowski M., Miduch A. (2010). Protein-xanthophyll concentrate-supplemented diet and lamb carcass quality. In: Alfalfa in human and animal nutrition, Grela E.R. (ed.). Stow. Rozwoju Regionalnego i Lokalnego "Progress" Dzierdziówka-Lublin, 6: 182-183.

Priolo A., Micol D., Agabriel J. (2001). Effects of grass feeding systems on ruminant meat colour and flavour. A review. Anim. Res., 50: 185-200.

Rechulicz J., Stec M. (2008). Influence of protein-xanthophyll (PX) concentrate of alfalfa on common carp (Cyprinus carpio) growth. In: Alfalfa in human and animal nutrition, Grela E.R. (ed.). Stow. Rozwoju Regionalnego i Lokalnego "Progress” Dzierdziówka-Lublin, 3: $129-137$.

R e shef G., Gest e tner B., B irk Y., B on di A. (2006). Effect of alfalfa saponins on the growth and some aspects of lipid metabolism of mice and quails. J. Sci. Food Agricult., 27, 1: 63-72.

S e g u in P., Z h en g W., S o u l e i m a n o v A. (2004). Alfalfa phytoestrogen content: Impact of plant maturity and herbage components. J. Agron. Crop Sci., 190: 211-217. 
Szu macher-Strabel M., Cieślak A. (2010). Secondary plant metabolites in ruminant nutrition. Studia i Raporty IUNG-PIB, 23: 35-71.

Szumacher-Strabel M., Hejdysz M., Nowak B., Dybiec M., Hoppe M., Zmora P., C i és la k A. (2010). Effect of alfalfa as a source of triterpenoid saponins on protozoa counts. In: Alfalfa in human and animal nutrition, Grela E.R. (ed.). Stow. Rozwoju Regionalnego i Lokalnego "Progress" Dzierdziówka-Lublin, 6: 194-195.

Szy manow ska A., Pat kow ski K., Gruszecki T.M., Grela E.R., Szy manowski M., M i d u c h A. (2010). Slaughter results of lambs fed protein-xanthophyll concentrate-supplemented feed. In: Alfalfa in human and animal nutrition, Grela E.R. (ed.). Stow. Rozwoju Regionalnego i Lokalnego "Progress" Dzierdziówka-Lublin, 6: 184-185.

Tartari E., Benatti G., Destefanis G., Bosticco A., Zoccarato I., Brugiapag 1 i a A. (1992). Lucerne leaf protein concentrate for growing/finishing pigs. L'impiego del concentrato proteico di medica nell'alimentazione del suino pesante. Riv. Suinicolt., 33 (1): 31-34.

U e d a H., O h s h i m a M. (1989). Nutritive value of alfalfa leaf protein concentrate prepared from low saponin variety in chicks and pigs. Japan. J. Zoot. Sci., 60 (6): 561-566.

W ang D., Fang J., Xing F., Y ang L. (2008). Alfalfa as a supplement of dried cornstalk diets: Associative effects on intake, digestibility, nitrogen metabolisation, rumen environment and hematological parameters in sheep. Livest. Sci., 113: 87-97.

Y e n J.T. (2004). Dehydrated alfalfa meal reduces urinary urea excretion in finishing gilts. J. Anim. Sci., Suppl., 82, 2: p. 68.

Young O.A., Lane G.A., Priolo A., Fraser K. (2003). Pastoral and species flavour in lambs raised on pasture, lucerne or maize. J. Sci. Food Agric., 83: 93-104.

Za górka G., Głowniak K. (2008). Evaluation of biological activity of alfalfa (Medicago sativa L.) active constituents based on in vitro and in vivo experiments. In: Alfalfa in human and animal nutrition, Grela E.R. (ed.). Stow. Rozwoju Regionalnego i Lokalnego "Progress" Dzierdziówka-Lublin, 3: 39-48.

$\mathrm{Z}$ a $\mathrm{n}$ in V. (2009). A new nutritional idea for man: lucerne leaf concentrate. In: Positive health impact of alfalfa's leaves extract in human nutrition, Maj R., Zioło Z., Kowalczuk-Vasilev E. (eds). Stow. Rozwoju Regionalnego i Lokalnego "Progress” Dzierdziówka-Lublin, 4: 15-46.

Accepted for printing 20 III 2012

\title{
ELIZA GAWEŁ, MIECZYSŁAW GRZELAK
}

\section{Wpływ stosowania koncentratu białkowo-ksantofilowego z lucerny (fitobiotyku) na efekty produkcyjne zwierząt}

\author{
STRESZCZENIE
}

Jednym z dodatków zastępujących antybiotykowe stymulatory wzrostu może być koncentrat białkowo-ksantofilowy z lucerny. Zielonka z lucerny posiada bardzo korzystny dla zwierząt skład chemiczny, zawiera 17-22\% białka ogólnego zasobnego w aminokwasy egzogenne, kwasy tłuszczowe nasycone, kwasy tłuszczowe: jednonienasycone, wielonienasycone, witaminy oraz składniki mineralne i kwasy organiczne. Zawartość włókna surowego w zielonce lucerny jest stosunkowo wysoka i kształtuje się na poziomie około 230-300,0 g/kg suchej masy. Zawartość włókna surowego w ekstrakcie białkowo-ksantofilowym PX otrzymanym z liści lucerny jest niewielka i wynosi około 1-2\%. Koncentrat białkowo-ksantofilowy podobnie jak całe rośliny lucerny zawiera wtórne metabolity roślinne, jak fitoestrogeny: izoflawony i kumestrol i składniki antyodżywcze: fityniany, L-kanawanina oraz saponiny.

Celem opracowania o charakterze przeglądowym było zebranie literatury omawiającej efekty stosowania koncentratu białkowo-ksantofilowego w żywieniu zwierząt. 
Koncentrat białkowo-ksantofilowy (PX) jako naturalny dodatek paszowy pozytywnie wpływa na organizm zwierząt. Wykazano lepsze efekty produkcyjne, zwiększenie wykorzystania paszy, poprawę jakości mięsa, mleka i jaj po suplementacji diety zwierząt tym koncentratem. Zaobserwowano też zmniejszenie emisji metanu i skażenia środowiska glebowego związkami azotu w warunkach stosowania PX w żywieniu zwierząt. 